\title{
The Theory of Practice Teaching System in Colleges and the Effective Measures to Cultivate Innovative Talents
}

\author{
Zhang Rong \\ Department of Mechanical Engineering, Dalian Vocational \& Technical College, Dalian, Liaoning, \\ 116037, China \\ Lzhch11993@sina.com
}

Keywords: The practice teaching; The student ability; Theory teaching; Innovative talents; Effective measures

\begin{abstract}
Practical teaching is an important part of college teaching, which is of great significance to cultivate students' practical ability, innovative thinking and scientific research ability. At present, there is a phenomenon in the teaching of universities that theory teaching, teaching team construction and the assessment system are out of touch. Therefore, Chinese university education has to strengthen the practical teaching links, create conditions for students potential development and creative ability play.
\end{abstract}

\section{The Necessity and Importance of Practice Teaching for Training Students' ability}

Practice teaching is an important link of the whole teaching activities of institutions of higher learning, it contains the experiment, practice, course design, practice and a series of practical teaching links, have very strong visual and operational, is added to the teaching of theory and expand. Is to provide students with a book knowledge into ability important place..

The Practice Teaching to Improve Students' practical Ability. Practical ability is the essential ability of innovative talents, it is the student to obtain knowledge through practice and the ability to apply knowledge to practice, is in the continuous development of the practice teaching activities. Practical ability is not only an important way for learning knowledge, also is the important basis for the development of intelligence [1].

On the one hand, the students in the school of practical, hands-on, experience knowledge generation process, providing students with the chance of a lot of doing, brain, saying, arouse students' interest in independent thinking, active learning, improve the students' practical application ability and practice ability; Students, on the other hand, through various forms of practice teaching, such as to participate in social survey, to the enterprise to participate in the life practice, such as forms of practice teaching, students in the process of practice organization, propaganda and so on to improve the ability to express, organization ability, communication ability, to explore, experiment and manufacture, also get exercise and improve the practice ability.

The Practice Teaching to Cultivate Students' innovative Thinking. Practice teaching is not only the students' wisdom and knowledge, is also the comprehensive performance of ability and quality, through the practice teaching activities, to improve college students' innovation ability of science and technology. One is to cultivate students' innovation consciousness. Through to participate in the practice teaching, students can find areas of science and technology have many unanswered questions waiting for people to study, easy to attract students' curiosity and attention [2]. At the same time, encourage students to think, to solve, and trigger the students' interest in issues of research and innovation desire, inspires students innovation consciousness. 2 it is to cultivate students' innovative personality. Through practice teaching activities, be helpful for students to develop individuality, is for students, according to their aptitude, not stick to one's personality cultivation. Students participate in teaching activities, but also overcome the setback, adjust the mentality, the process of continuous improvement, help to cultivate the spirit of the strict truth-seeking style, collaborative research, tenacious character.

The Practice Teaching Exercise the Students' scientific Research Ability. Scientific research is an important part of the practice teaching is the integrated use of theoretical knowledge, and use a 
variety of scientific method system to solve a particular subject or topic production process. On the one hand, students in the process of project, for the accumulation of scientific research methods, research data, the scientific research design, application of selected topic and research subject, research paper writing, submissions and published about the basic content of scientific research, master the basic knowledge of the scientific research; , on the other hand, students to participate in and complete the task in the process, through the guidance of teachers, mastered the basic ideas of scientific research, and under the guidance of the teacher independent literature, translation materials, processing data, and write a report, the students must carefully think, take the initiative to seek a solution to the problem, make the students' thinking is not constrained by experiments had decided good program, help to improve students' thinking, the ability to design, test and scientific research ability.

\section{The Main Problems in the Practice Teaching in Colleges and Universities}

Practice Teaching with Theory Teaching. In higher education has long been existed the tendency of light practice focuses on theory, emphasis on "knowledge" and despising "ability", Attached to the classroom teaching mostly experiment teaching at the same time, make the classroom teaching and practice teaching disconnect: one is the practice teaching classes on disconnect. Think the practice teaching is teaching theory. So on the arrangement of the practice teaching is a practice what content, what conditions guaranteed theory class hours, how much can be left school hours arrangements how much practice, practice to a serious shortage of class hours. Secondly, the practice base can't meet the requirements of theoretical teaching. At present, the increasing cost of running and uncertainty sources of funding has become a worldwide higher education faces serious financial problems.

From the perspective of colleges and universities in China, the sources of funds is mainly local fiscal appropriations of colleges and universities tend to be more serious situation, insufficient funds inevitably leads to practice base is not effective. Due to the large number of enrollment expansion of colleges and universities, a lot of theoretical teaching of about 120 people in each shift. Have to a few people a set of complete an experiment, far cannot meet the needs of students' practice. Three is heavy theory, light practice course construction. Due to the government's assessment of the quality of higher education are widespread prejudice "high quality", emphasize that enrollments, key disciplines and the number of published papers of pure academic factors, neglect the construction of practice teaching link. Many colleges and universities the experiment technicians as tutors, think the experimental technical personnel's job is to keep the instrument, to experiment, to assist teachers with experiment, is a low level of teaching, and also increase the theory teaching, scientific research on curriculum construction, and ignore the construction of practice.

The Practice Teaching and Teachers Team Construction. Teachers and students are the main body of practice teaching, teachers play a leading role. Currently engaged in the practice teaching of teachers as a whole exists irrational knowledge structure, the relatively single teaching mode: one is the insufficient ideological understanding, with a strong heart. Because practice teachers in the achievement, not easy work, make the teachers' work is not responsible for the experimental teaching, through various channels to improve education, to teachers work in the theoretical teaching. Secondly, the practice ability is weak [3]. Most of the current college teacher is from school to school, from theory to theory, the pulpit, neither comfortable working in the laboratory, and a lack of scientific research practice, combined with heavy teaching tasks, to practice exercise time serious lack of practical ability is weak. Three is a team structure is not reasonable. The personnel engaged in practice teaching, mainly technical workers, title generally low, and most is close to retirement age. In order to replenish the practice teaching, universities in the introduction of highly educated talents, families didn't place is arranged in the lab.

Practical Teaching and Examination Evaluation System. Now implement the teaching of the course in colleges and universities, mostly based on theory teaching is given priority to, its 
curriculum evaluation system, and mainly course examination: one is the exam form is single. Most of course exam is still confined to a request for the final exam, and all is conducted by theoretical knowledge. Test the chance is very big, can't give play to the role of test feedback on students' comprehensive quality, and the requirement of cultivating creative talent. Secondly, the practice teaching evaluation is not sound. Most colleges and universities are not specialized practice teaching evaluation measures and evaluation standards. The practice of various curriculum assessment, mostly in the form of grades, it also according to the arrangement of the teacher to decide, less proportion of total score. Because the inspection is not strict, practice is just a formality, students don't go to unit internship, when open a letter of introduction, write a report to finish, reach the purpose of practice teaching. Three is the lack of a proper incentive mechanism. Practice teaching in a variety of forms, such as extracurricular activities of science and technology, small inventions, create, to take part in the investigation of teachers' scientific research projects and take part in social practice, etc., most colleges and universities not give corresponding credits, severely dampened the enthusiasm of students to participate in the practice teaching.

\section{Building a Practical Teaching System is the Effective Measure to Cultivate Innovative Talents}

Practice teaching can not only improve the students' practical ability, more important is to cultivate students explore the formation process of discipline, to participate in the enthusiasm of scientific research and ability, innovation ability and comprehensive quality training for link. Colleges and universities must strengthen the research of practical teaching, change the practice teaching values, the present situation of the relatively weak, in order to improve the innovation ability of students to lay a good foundation.

Building Scientific Practical Teaching Plan is the basis of practice teaching. Cultivate students' innovative spirit and practice ability is a component part of higher education, has become one of the core content of education in colleges and universities, to design and build a scientific and reasonable practice teaching mode is the inevitable requirement of cultivating innovative talents in colleges and universities. First of all, to complete the practice teaching plan. The plan to student development as the basis, the main content should include: training target, teaching content, class, teaching methods and means and practical teaching assessment, etc., meet the students in the form of more than four years uninterrupted, the requirement of the practice teaching, so as to ensure the quality of teaching, also is advantageous for the organization and implementation. Next, practice teaching should have hierarchy: Is a basic practice teaching, mainly for junior students' background knowledge, through the engineering training center outside the base of cognition practice, campus, stimulate students' thirst for knowledge and professional interest; Two is the basic course of the experiment, in view of the basic subjects such as physics, mathematics, computer and professional basic course experiment, let the student through confirmatory experiments to find and solve problems, to cultivate the students' practice ability and innovation consciousness; Three is a specialized course teaching practice, mainly for the seniors, through the specialized course experiment, course design, field practice and comprehensive practice, graduation thesis research to make the students become the discoverer of the combination of theoretical knowledge and practical use and creator, through the three levels of practice teaching to cultivate students' innovation consciousness. Training the students' various abilities so as to cultivate the students' scientific research ability and innovation ability [4].

To Optimize the Practice Teaching Management Mechanism is the Basis of Practice Teaching. Security. practice teaching management refers to the practice teaching plan, organization, coordination, command and control, optimize the practice teaching management mechanism, the purpose is to strengthen the practice teaching standardization construction, to guarantee the realization of the practical teaching process with the system. A mechanism is to establish a practical teaching responsibility. In order to ensure that the practice effect of the practice teaching, the practice base should implement responsibility system, the scientific research ability and practice ability of the head of the teachers in the practice teaching, ensure that the construction of practice base and implementation. The second is to build a practical teaching incentive 
mechanism [5]. Practice teaching of the incentive mechanism, both teachers incentive, also have the students' active participation. On the one hand to take measures to mobilize the enthusiasm of teachers to participate in the practice teaching, the quality of practice teaching reward excellent teachers; Set up, on the other hand, extracurricular quality credit, improve the enthusiasm of students. Three is to establish and perfect the practice teaching quality assessment system. Attaches great importance to and strengthen the practice teaching, in the teaching evaluation should pay attention to both the evaluation of the effect of classroom teaching, also should pay attention to practice teaching effect assessment. Practice teaching quality is a comprehensive index, the school should be according to the implementation of the measures for the management of credit system, the productive labor and social practice, production practice and practice teaching should be set clear teaching requirements and assessment method, should not only strengthen the evaluation of teachers, put in place to ensure that the practice teaching, and evaluation of students, to examine the effects of practice teaching.

Establishing Practice Teaching Faculty is the Key to Develop Practice Teaching. To really do a good job of the practice teaching, an important teaching link to implement, and obtain due effect, the practice teaching faculty is the important guarantee. Colleges and universities should realize that in the modern sense of practice teaching staff is no longer the traditional concept of "tutors", they are the main body of teaching activity. Therefore, colleges and universities should strengthen the construction of teaching faculty [6]. To provide conditions for the development of teachers, to study in famous universities, companies, enterprises or credentials the exercise, for teachers to provide the opportunity to carry out scientific research and strengthen the practice ability, to make them as soon as possible do theory with practice, improve the practice ability, to lay a good foundation for the practice teaching. Second, we must hire companies and enterprises practice ability of experts and teachers as students practice guidance teachers, guide students to practice activities, improve the ability of practice teaching under the guidance of teachers. Third, we need to provide opportunities for the various kinds of continuing education of teachers, for teachers to update the knowledge, understanding and absorbing the latest research achievements provide convenient. It through the way of "please come in and go out", in the practice teaching team has plenty of both a higher level of professional theory, and has the strong practice ability; Both understand the workings of the enterprise, and master the law of education "double type" teachers.

\section{Conclusion}

Social fierce competition requires that we must change traditional mainly teaches the theory of teaching model, only improve the students' innovation ability and practice ability can meet the demand of society is constantly changing. Therefore, how to cultivate and enhance students' innovation spirit, improve the practical ability of college students is an eternal subject education workers. As a 21st century college students, more should dare to innovate, the courage to practice. Although innovation means may make mistakes, practice means may fail, but so what? As we for the choice of youth: not done no wrong, but beg conscience clear.

\section{References}

[1] DeXian Fu. Theory of practice teaching and the cultivation of innovative spirit and ability. Journal of hubei radio and TV university[J]. 2001,(9).

[2] Weifang Ming. Higher education operating mechanism research[M].. Beijing: people's education press. 2002.

[3] Zongxiang Peng.College students' innovation to create reader [M]. Shanghai, east China university of science and technology press.2003.

[4] Shankai He. Practice the subjective[M].2001.

[5] Kuang Ying, Comparision of Higher Vocational Education. Development and Change[M], 
Shanghai Education Press. 2016.10.

[6] Frederick E. Giesecke, Alva Mitchell, Henry C Spencer, et al. Modern graphics communication (Third Edition)[M]. American: Pearson Prentice Hall, 2004. 1-601 